\title{
PENGUJIAN ANOMALI PASAR SIZE EFFECT DAN THE DAY OF WEEK EFFECT DIBURSA EFEK INDONESIA
}

\author{
Oki Tjandra Suryo Kurniawan ${ }^{1}$ \\ IB. Anom Purbawangsa ${ }^{2}$ \\ ${ }^{1,2}$ Fakultas Ekonomi dan Bisnis Universitas Udayana, Bali, Indonesia \\ e-mail : tjandra.hartoyo@gmail.com
}

\begin{abstract}
ABSTRAK
Pasar modal sebagai tempat perusahaan mendapatkan dana dengan menjual beberapa saham dengan investor ditujukan mendapatkan return maksimum. Tujuan penelitian ini untuk menguji adanya gejala fenomena Size Effect dan The Day of Week diBursa Efek Indonesia. Sumber data menggunakan saham sektoral periode Januari 2017 - Juli 2017 sebanyak 21 perusahaan dengan teknik purposive sampling. Terdapat dua kelompok saham yaitu saham berkapitalisasi besar dan saham berkapitalisasi kecil, analisa dengan uji One Way-ANOVA dan Independent Sample T -test. Hasil penelitian tidak terdapat fenomena size effect dan The Day ofWeek effect disebutkan return terkecil hari Selasa (Tuesday effect) serta return terbesar hari Rabu. Hasil pengujian ukuran perusahaan terhadap hari perdagangan terdapat perbedaan dikarenakan lemahnya daya beli masyarakat periode tersebut. Saran bagi investor tidak bergantung pada anomali pasar saat pengambilan keputusan berinvestasi.
\end{abstract}

Kata Kunci : Return Saham, Size Effect, The Day of Week effect

\begin{abstract}
A capital market in which a company obtains funds by selling several shares with an investor is required to obtain maximum return. The purpose of this study was to examine the symptoms of phenomena Size Effect and The Day of Week in Indonesia Stock Exchange. Sources of data using sectoral shares in the period of January 2017 - July 2017 as many as 21 companies with purposive sampling technique. There are two groups of stocks that are large capitalized stock and small capitalized stock, analysis with One Way ANOVA test and Independent Sample T test. The results of the study there is no phenomenon of size effect and The Day of Week - effect mentioned the smallest return on Tuesday (Tuesday effect) and the biggest return on Wednesday. The result of firm size test on trading day there is difference due to the weakness of public purchasing power of that period. Suggestions for investors do not depend on market anomalies when making investment decisions.
\end{abstract}

Keywords : Stock return, Size Effect, The Day of Week Effect 
Oki Tjandra Suryo Kurniawan, dan IB. Anom Purbawangsa. Pengujian Anomali Pasar...

\section{PENDAHULUAN}

Dalam berinvestasi, tujuan utama adalah mendapatkan nilai return yang optimal yaitu dengan membeli aset yang memiliki pendapatan tertinggi dengan resiko tertentu sehingga investor memerlukan informasi historis untuk mengetahui pergerakan harga saham masa lalu pada periode tertentu dalam bentuk indeks harga saham, dimana indeks harga saham menjadi hal penting bagi investor untuk menentukan apakah akan menjual, membeli ataupun menahan saham tersebut. Dalam berinvestasi dipasar modal, pihak investor akan diberikan pilihan diantaranya jika investor memilih beberapa investasi maka resiko dibebankan hanya investasi itu sehingga untuk meminimalisir kerugian pihak investor tidak hanya berinvestasi di satu saham saja untuk mendapatkan return yang optimal.

Dalam pasar modal, pemerintah Indonesia memiliki peran melalui UU RI No. 8 Tahun 1995 disebutkan bahwa pasar modal berperan dalam pembangunan, sebagai pedoman bagi ranah usaha dan investasi masyarakat luas. Fahmi (2013) menjelaskan arti pasar modal secara dasar sebagai tempat banyak pihak khususnya perusahaan menjual saham atau obligasi yang bertujuan hasil penjualan dipakai untuk tambahan dana. Selain itu pasar modal oleh beberapa perusahaan dipakai memperbanyak kebutuhan dana dengan menjual saham / mengeluarkan obligasi untuk jangka panjang. Pasar modal pertama kali diperkenalkan oleh Eugene Fama tahun 1970 dimana didefinisikan harga sekuritas sebagai pedoman informasi yang ada, definisi tersebut terdapat istilah fully reflect yaitu harga beberapa sekuritas dengan tepat menjelaskan informasi suatu pasar dan informasi yang berlaku yang dijelaskan sebagai informasi yang tersedia sehingga investor 
menggunakan harga sekuritas tersebut. Berikut beberapa hubungan tingkatan efisiensi pasar berdasarkan berdasar tingkat informasi :

\section{Tingkat Efisiensi}

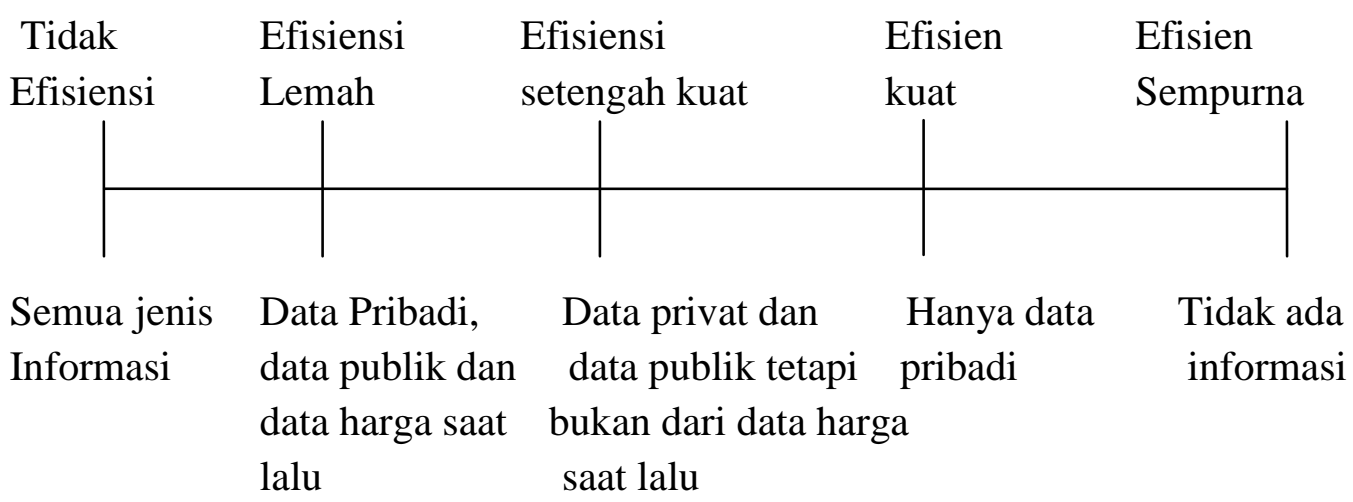

\section{Tingkat Informasi}

\section{Gambar 1.1 Hubungan keterkaitan pandangan seseorang tentang pasar efisien pada pasar modal}

Gambar 1.1 menjelaskan dalam tingkat efisiensi pasar, dikelompokkan menjadi lima kelompok yaitu pasar tidak efisien sebagai pasar efisien terendah dan pasar efisien sempurna sebagai pasar efisien tertinggi, dimana tingkat efisiensi pasar dan tingkat informasi saling terkait. Misalkan pada pasar tidak efisien dikatakan, jika semua informasi tersedia dan ditujukan untuk mendapat beberapa abnormal return tersebut sedangkan pasar efisien sempurna dikatakan jika tidak ada informasi dipergunakan untuk mendapat abnormal return di pasar. Anomali dalam pasar adalah hasil empiris yang berlawanan menyebabkan bentuk pasar tidak efisien (Jones: 2014). Hal ini terjadi dikarenakan banyaknya pihak dan berbagai macam faktor yang terlibat sehingga menyebabkan munculnya penyimpangan. Menurut Anwar dan Mulyadi (2009) menilai anomali diperlukan untuk memutuskan strategi dalam investasi, anomali yang ada ikut berpengaruh 
Oki Tjandra Suryo Kurniawan, dan IB. Anom Purbawangsa. Pengujian Anomali Pasar...

pada efficiency market dikarenakan saat nilai pada aset tidak berubah tetapi investor dapat melakukan prediksi dengan cara menggunakan anomali, sehingga disisi lain kegunaan anomali adalah membantu para investor dalam menganalisa return tidak normal.

Jogiyanto (2005) menyebutkan ada beberapa jenis anomali yang terjadi, yaitu anomali karena strategi price earning ratio (PER) rendah (Low P/E Ratio), anomali karena efek ukuran perusahaan (size effect), anomali efek jangka panjang dan anomali efek jenis kalender disebabkan periode periode tertentu mengeluarkan return tertinggi dibandingkan periode yang lain, ini dikarenakan efek waktu dalam hari (time of the day effect), efek hari mingguan (the day of the week-effect), efek bulanan dalam setahun (month of the year-effect). Selain itu beberapa penelitian tentang anomali efek kalender diantaranya the day of the week-effect, Monday-effect, week four-effect, January-effect serta rogalski-effect.

Fenomena anomali size effect pertama kali dijelaskan oleh Banz dan Reinganum tahun 1981 dan anomali ini menjadi hal cukup menarik dalam bidang keuangan disebabkan penelitian anomali ini sebelumnya sudah dilakukan pada pasar modal Internasional, Jones (1996) dalam penelitiannya menjelaskan size effect suatu anomali yang menunjukkan perusahaan kecil menghasilkan risk adjusted retun lebih tinggi dari perusahaan besar. Begitu juga menurut peneliti lainnya dilakukan oleh Reinganum tahun 1992 menjelaskan saham perusahaan kecil mampu menghasilkan return tertinggi dari saham besar, tidak selalu setiap tahun melainkan waktu tertentu tertentu mengulang. Sedangkan Brown dan Marsh (1983) ikut berasumsi sama bahwa size effect tidak terjadi tiap tahun sehingga 
pada size effect, adanya karateristik dan keadaan pasar modal yang berlainan di return saham halnya pasar modal di beberapa negara didapat hasil yang berlainan. Penelitian ini bertujuan mencari solusi dan kesimpulan apakah anomali size effect terbukti di BEI dan sekaligus menguji hipotesis pasar yang efisien di Indonesia sehingga dapat disimpulkan penelitian ikut berefek pada perdagangan jenis saham di Indonesia.

Size effect pertama kali ditemukan oleh Banz dan Reinganum tahun 1981 dan anomali ini menjadi hal cukup menarik dalam bidang keuangan disebabkan penelitian anomali ini sebelumnya sudah dilakukan pada pasar modal Internasional, Jones (1996) dalam penelitiannya menjelaskan size effect suatu anomali yang menunjukkan perusahaan kecil menghasilkan risk adjusted retun lebih tinggi dari perusahaan besar. Begitu juga menurut peneliti lainnya dilakukan oleh Reinganum tahun 1992 menjelaskan saham perusahaan kecil rata rata menghasilkan return tertinggi dari saham besar dan tidak berlaku setiap tahun melainkan ada periode tertentu. The day week-effect anomaly ialah kejadian return saham terkecil pada hari senin dibanding return saham perdagangan periode berbeda. Penelitian anomali ini adalah bagian dari teori pasar efisien dimana return saham setiap hari perdagangan tidak berbeda, tetapi menjelaskan adanya perbedaan return beberapa hari perdagangan dalam seminggu dan pada hari senin rata rata menghasilkan return negatif. Beberapa faktor lain yang mempengaruhi return adalah psikologi investor (Rystrom dan Benson : 1989). Pada The day of week-effect anomaly, anomali tidak terjadi dihari Senin disebabkan banyaknya investor melakukan perdagangan di hari Jumat karena adanya nilai negatif pada 
Oki Tjandra Suryo Kurniawan, dan IB. Anom Purbawangsa. Pengujian Anomali Pasar...

hari Senin. Banyaknya nilai negatif karena beberapa hal, seperti proft taking dilakukan investor dihari Jumat. Waktu tepat membeli saham bagi investor adalah awal pemakaian bursa hari Selasa dikarenakan adanya harga saham bernilai rendah di hari Senin. Adanya return negatif dihari Senin disebabkan mayoritas investor menganalisa informasi yang masuk kepasar dan menyusun strategi, sehingga akan menunda bertransaksi jual beli saham. Kebanyakan para investor cenderung kurang menyukai hari Senin sehingga ikut mempengaruhi niat dalam melakukan penjualan saham. Setelah periode Senin atau akhir pekan, investor mulai merancang strategi jual dan beli jenis saham mendapat laba maka ada kenaikan return saham di hari perdagangan pada hari Selasa sampai dengan pada hari Jumat. Beberapa penelitian terjadi the day the week-effect dimacam negara, seperti hasil penelitian Keim dan Stambaugh (1984) menunjuk kesalahan pada saat pengukuran, penelitian dilakukan Basher et.al tahun 2006 berjudul day of the week effect in emerging stock market menjelaskan bukti adanya the day of the week-effect, dimana dijelaskan bahwa negara Malaysia, Taiwan, Thailand dan Turki masing-masing menunjukkan adanya fenomena Monday Effect. Pakistan dan Filipina menunjukkan adanya fenomena Tuesday effect, Turki menunjukkan Thursday effect dan Taiwan menunjukkan adanya fenomena Friday Effect. Barument tahun 2001 melaporkan tingginya ketidaktentuan bisa merupakan dalih untuk munculnya informasi buruk di akhir pekan karena investor tidak bisa mendengar bad news tersebut di akhir minggu, investor menganalisa dengan laporan di hari Jum'at. Tingginya ketidaktentuan di hari Jum'at berharap mendapat premi jenis saham maksimal bertujuan mengurangi risiko otomatis 
wajib ditanggung, ini menjadi penyebab nilai return berbeda yang diterima investor setiap harinya.Penelitian penelitian The day week effect anomaly dalam negeri dilakukan oleh Pandiangan (2009) dengan hasil tidak terjadinya efek hari, efek minggu keempat, efek Januari dan terjadinya rogalski effect pada perdagangan return saham tahun 2008. Dwi Cahyaningdyah tahun 2005 menjelaskan terdapat day of the week-effect diBursa Efek Jakarta, return terendah pada hari senin (Monday-effect), maksimal return hari Jum'at (weekend-effect). Fitria (2009) menunjukan terdapat pengaruh baik tetapi tidak tetap hari perdagangan terdapat jenis pengaruh terbesar perdagangan hari Kamis. Dari latar belakang masalah, rumusan masalah 1). Apakah terdapat size effect di Bursa Efek Indonesia (BEI)? 2). Apakah terdapat adanya The Day of Week-Effect di Bursa Efek Indonesia (BEI)? 3). Apakah terdapat perbedaan hasil yang akurat return size effect dan The Day of Week-Effect di Bursa Efek Indonesia (BEI)?.Sedangkan tujuan kegunaan penelitian untuk mengetahui adanya fenomena anomali perusahaan di periode tersebut serta dapat memberikan informasi pada investor saat akan melakukan investasi.

Pengertian investasi yaitu penundaan jenis konsumsi sekarang digunakan periode waktu tertentu yang tepat (Jogiyanto: 2013). Pihak yang berinvestasi disebut dengan investor yang dikelompokkan dua yakni investor individual yaitu individu melakukan investasi serta investor jenis institusional yaitu perusahaan jenis asuransi, lembaga jenis penyimpanan dana, lembaga jenis dana pensiun serta perusahaan bidang investasi. Didalam aktiva, investasi dilakukan dalam bentuk investasi langsung seperti langsung membeli aktiva keuangan pada perusahaan 
Oki Tjandra Suryo Kurniawan, dan IB. Anom Purbawangsa. Pengujian Anomali Pasar...

dan investasi secara tidak langsung dilakukan membeli jenis saham beberapa perusahaan yang menjual saham di pasar modal yang sebagai faktor penting dalam perekonomian beberapa negara dikarenakan sebagai perantara para pemilih dana (investor) dengan para pemakai dana atau emiten dalam negara tersebut untuk keperluan investasi sehingga dapat menambah penghasilan. Sedangkan menurut Elton dan Grueber (1995) konsep pasar modal yaitu harga pada sekuritas menjelaskan informasi tersedia himgga batas dari biaya marginal guna memenuhi informasi, transaksi keuntungan jenis marginal. Peran dalam pasar modal sebagai cara perusahaan bertujuan menaikkan kebutuhan dalam jangka waktu panjang melalui mengeluarkan obligasi maupun menjual saham, fungsi lain pasar modal menurut Hartono (2014) adalah sebagai pengalihan dana produktif ke peminjam, pengalihan dana produktif jika suatu individu memiliki dana berlebih bisa meminjam pada pihak lebih produktif.

Konsep pasar berpedoman pada nilai intrinsik sekuritas diartikan sebagai pasar dengan nilai sekuritas yang tidak menyimpang dari nilai intrinsik, sehingga metode pengukuran efisiensi pasar berpedoman sejauh mana harga pada sekuritas yang keluar dari nilai jenis intrinsik. Nilai intrinsik pada efisiensi pasar bukan satu satunya konsep yang digunakan tetapi lebih berpedoman pada akurasi dari return ekspetasi, kemampuan pasar menyerap informasi dan ketersediaan informasi. Definisi sekuritas disebut efisien bila harga pada sekuritas pedoman secara total informasi yang ada tidak terlepas adanya dua hal yaitu fully reflect, menunjukkan jenis sekuritas yang akurat serta information available menjelaskan pasar dikatakan efisien bila menggunakan informasi tersedia sehingga infestor secara 
detail dapat memprediksi harga dari sekuritas yang bersangkutan. Pasar modal memiliki beberapa hipotesis yang berkaitan pada keseluruhan informasi seperti informasi lampau, informasi terkini dikeluarkan dan informasi bersifat pribadi yaitu : 1). Weak form hypotesis menjelaskan harga jenis saham menjelaskan semua informasi pada masa lampau. 2). Semi strong form hypotesis menjelaskan informasi harga saham bersifat publik, maksudnya mencerminkan tidak sekedar harga saham lampau tetapi juga informasi bersifat umum yang tepat pada perusahaan. 3). Strong form hypotesis menjelaskan informasi harga saham sesuai dan relevan bagi perusahaan maupun orang dalam pada perusahaan tersebut.

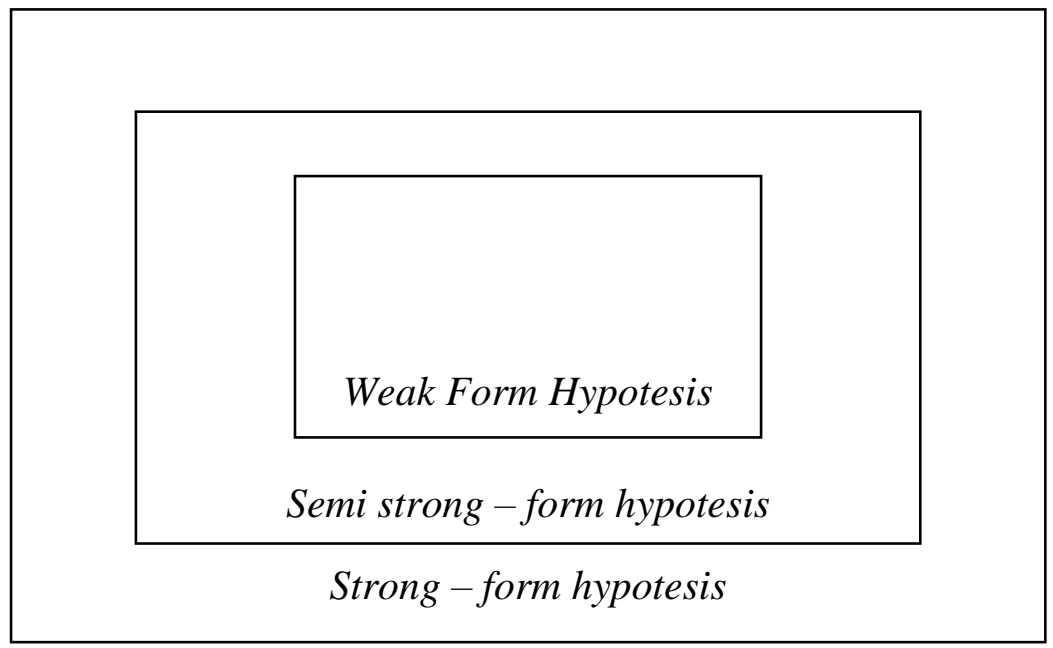

\section{Tingkatan Efisiensi Pasar Modal}

(Sumber : Jones, 2004)

Dalam konsep pasar efisien terdapat dua jenis style (pengambilan keputusan) investor yaitu active management style dan passive management style, sedangkan pada implikasi yang terjadi pada pasar modal diantaranya 1). Implikasi terhadap analisa fundamental. 2). Implikasi terhadap analisa tekhnikal. 3). Implikasi terhadap analisa aktif dan pasif. Dalam strategi pasif terdapat istilah strategi buy and hold yang berarti para investor dapat membeli dan menyimpan 
Oki Tjandra Suryo Kurniawan, dan IB. Anom Purbawangsa. Pengujian Anomali Pasar...

saham dalam waktu dan tujuan tertentu, tetapi para investor juga harus menyeleksi saham yang akan ditaruh dalam portofolio sesuai tujuan yaitu untuk mengikuti kinerja indeks pasar sedekat mungkin, hal ini sesuai dengan pengertian analisa pasif yaitu perilaku investor saat membuat portofolio saham sebagai bagian cara kerja indeks harga pasar.

Sifat utama dari pasar modal adalah bersifat efisien bertujuan agar pihak dana berlebih dapat melakukan transaksi kepada pihak yang memerlukan dana (lenders to borrowers) dengan cara investasi dana melalui sekuritas untuk mendapatkan return (hasil) yang lebih besar dalam pasar modal, selain itu pihak yang memerlukan dana dapat menggunakan untuk pengembangan bisnisnya sehingga nilai sekuritas mencerminkan nilai perusahaan tersebut. Selain berifat efisien, pasar modal harus bersifat likuid jika pihak pembeli dan penjual dapat bertransaksi jual beli sekuritas dengan cepat.

Menurut Yanuarta tahun 2012, adanya anomali dalam pasar modal dapat terjadi dikarenakan adanya tiga hal diantaranya : 1).Struktur pasar, tidak sempurna karena tidak ada pasar yang sungguh sungguh bisa disebut sempurna pada kenyataannya. 2). Munculnya kekuatan cukup besar dari penyimpangan tingkah laku oleh para investor yang melakukan perdagangan dan 3). Adanya teori pada pasar modal dipakai oleh investasi dalam melakukan strategi investasi kurang tepat sehingga bisa menyebabkan terjadinya kesalahan atau penyimpangan dalam penilaian pasar modal. 
Dalam suatu investasi, para investor melakukan investasi tersebut bertujuan untuk mendapat tingkat keuntungan berlebih sehingga baik investasi riil maupun investasi bentuk keuangan sehingga para investor selalu mencari keuntungan yang disebut dengan return (Robert Ang : 2010). Return saham dalam suatu investasi dapat berupa realization return dan expectation return (Jogiyanto:2013), pengertian realization return adalah return yang sudah terjadi bersumber pada data jenis historis. Dalam realization return, kegiatan investasi memiliki beberapa fungsi diantaranya sebagai pedoman kinerja, sebagai pedoman return ekspetasi dan resiko kedepan. Beberapa pengukuran return realisasi adalah secara kumulatif, relative, return disesuaikan dan return total. Sedangkan expectation return adalah pengembalian diharapkan investor dalam waktu mendatang, tingginya return saham tersebut mengindikasikan saham tersebut aktif diperdagangkan.

Pengertisan saham menurut Fahmi tahun 2013 menyebutkan sebagai kepemikikan saham suatu perusahaan dalam bentuk tanda bukti. Beberapa karateristik saham diantaranya adalah 1). Ultimate Control, arah dan tujuan perusahaan secara penuh dikendalikan pemilik saham 2).Residual Claim, dalam pembagian usaha dalam bentuk deviden dan sisa asset maka pemegang saham adalah pihak terakhir yang mendapatkannya dan 3). Limited Risk, hanya bertanggung jawab sampai jumlah yang disetorkan pada perusahaan. Total return terbentuk gabungan yield dan loss (capital-gain). Loss (capital-gain) adalah suatu kelebihan dikarenakan terjadinya pengurangan harga beli saham dan harga jual saham, sedangkan yield adalah bagian return aliran kas yang didapat secara waktu 
tertentu suatu investasi. Dalam yield, besarnya sesuai dengan besarnya dividen, sehingga total return merupakan gabungan capital gain dan yield. Dalam penyelesaian dapat ditulis :

$$
\text { Return Total }=\text { Capital gain }+ \text { yield }
$$

Dimana nilai yield didapat dari :

$$
\text { Yield }=\frac{D_{t}}{P_{t-1}}
$$

Dari penjelasan tersebut, nilai dari return total adalah :

$$
\text { Return total }=\frac{P_{t}-P_{t-1}}{P_{t-1}}+\frac{D_{t}}{P_{t-1}}=\frac{P_{t}-P_{t-1}+D_{t}}{P_{t-1}}
$$

Dimana :

$P_{t} \quad=$ Harga jenis saham saat ini

$P_{t-1}=$ Harga jenis saham sebelumnya

$D_{t} \quad$ = Dividen yang dibayarkan

Perusahaan yang memiliki saham berkapitalisasi besar (big-cap / blue chip) adalah perusahaan yang memiliki saham berkapitalisasi besar diatas lima triliun dan biasanya memiliki kondisi keuangan terbaik dan menghasilkan produk terbaik yang dijual secara merata. Menurut Sihombing (2008) secara tekhnikal, saham berkapitalisasi besar memiliki nilai koefisien beta terendah dibandingkan dengan jenis saham lapis kedua saham lapis ketiga (small-cap) ataupun volatilitas harga yang rendah serta memberikan pengembalian modal yang jelas. Beberapa alasan investor jika memilih saham berkapitalisasi besar diantaranya : 1). Manajemen yang handal dan mengutamakan keamanan. 2). 
Jumlah kenaikan harga saham secara historis sangat tinggi dan 3). Dibanding harga saham non big-cap, harganya mengalami recovery lebih cepat saat terjadi aksi jual.

Sedangkan pada perusahaan yang memiliki saham berkapitalisasi kecil (small-cap) adalah perusahaan yang memiliki saham berkapitalisasi besar dibawah lima triliun biasanya memiliki nilai beta tinggi dan pergerakan harian tertinggi. Hal ini dikarenakan tidak mengikuti pola pergerakan harga saham bigcap maupun second liners dibandingkan ukuran saham lainnya (Sihombing:2008). Kejadian ini dimanfaatkan oleh investor untuk mendapat keuntungan yang besar. Beberapa cara yang digunakan investor untuk mendapat saham small-cap yaitu : 1). Mencari saham yang masa lalu pernah mengalami kenaikan tertinggi sebelum kembali ke titik terendah.2). Mencari saham small-cap yang masuk pada kelompok sektor usaha pertumbuhan tertinggi 3). Secara tekhnikal, harga saham memenuhi syarat untuk naik dan 4).Mengikuti secara rutin informasi dari saham tersebut.

Adanya kejadian anomali pada pasar modal diantaranya size effect dan The Day of Week effect yang sebelumnya pernah diteliti dengan periode dan jenis saham yang berbeda yang terdaftar di Bursa Efek Indonesia. Dengan karateristik dan kondisi pasar modal yang berbeda beda dimungkinkan mendapatkan kesimpulan yang berbeda. Hasil yang ditujukan dalam penelitian ini adalah jawaban dan kesimpulan apakah anomali Size Effect dan The Day of Week mempengaruhi return saham pada perusahaan di Bursa Efek Indonesia dan 
Oki Tjandra Suryo Kurniawan, dan IB. Anom Purbawangsa. Pengujian Anomali Pasar...

sekaligus untuk menguji tingkatan hipotesis pasar efisien di Indonesia, hal ini secara tidak langsung akan berimplikasi dalam perdagangan saham di Indonesia.

Dalam penelitian ini, pengujian pendugaan return dibahas dikarenakan ikut melibatkan pengujian pasar bentuk lemah, pengujian bentuk lemah saling terkait pada hipotesis secara langkah acak atau random walk hypothesis, maksudnya adalah harga bersifat pola langkah acak, harga akan berubah dari waktu dan memiliki sifat random independent maka harga berubah saat ini tidak terkait dengan harga berubah sebelumnya. Beberapa cara pengujian pasar bentuk lemah yaitu menggunakan pengujian statistik / aturan teknis (technical trading rules). yaitu analisa independensi pada perkembangan harga sekuritas, jika hasilnya adalah independensi harga, pihak investor tidak menggunakan nilai lampau pada variabel-variabel sementara seperti harga, return, dividen, yield, maupun tingkat suku bunga pada penduga harga atau return saat ini. Pasar efisien bentuk yang lemah dicirikan dengan adanya tidak tetapnya harga sekuritas yang independent pada nilai lampau variabel penduga. uji statistik digunakan untuk menguji independensi yakni uji hubungan terhadap variabel dengan korelasi bersifat serial atau regresi bentuk linear maupun run test. Fungsi dari uji pasar bentuk lemah ditujukan untuk menguji ada atau tidaknya return sekuritas masa lampau dengan return sekuritas saat ini / kedepan. Adanya hubungan sama antara dua waktu perubahan harga dihitung dengan koefisien bersifat korelasi / memakai teknik regresi, disimpulkan jika harga berubah antar waktu tidak penting maka terdapat independensi pada harga sekuritas dari waktu ke waktu yang lain, maka suatu pasar modal dapat dikatakan sudah efisien dalam bentuk lemah. Selain tekhnik 
regresi, dapat juga menggunakan run test tekhnik., Run test yaitu urutan tanda sejenis pada nilai berubah dimisalkan pada harga sekuritas meningkat bernilai positif, harga sekuritas menurun diberi negatif dan harga sekuritas tetap diberi tanda nol. Jika harga sekuritas dari waktu ke waktu positif maka terjadi perubahan yang sedikit tanda atau run test yang sedikit, sedangkan harga sekuritas dari waktu ke waktu negative maka terjadi perubahan yang banyak tanda atau run test yang sedikit tanda negatif atau akan banyak terjadi run test.

Harga pasar merupakan suatu harga pada saham yang masih berlangsung dalam bursa efek yang pasar saat penutupan (closing price) bertujuan meningkatkan nilai kapitalisasi pasar (Gumanti, 2011). Harga saat penutupan selalu dijadikan acuan dalam naik turunnya suatu nilai saham sehingga market value didapatkan dengan total saham terbit / outstanding share dikalikan harga pasar. Bila ditulis dalam bentuk persamaan :

$$
V_{s}=S_{s} \times P_{s}
$$

Dimana

Vs = Kapitalisasi Pasar (Market Value)

Ss = Jumlah saham yang terbit

Ps = Harga Pasar (Market Price)

Jones (2014) menjelaskan anomali adalah hasil empiris yang berlawanan menyebabkan bentuk pasar tidak efisien. Dalam pasar modal beberapa anomaly yang diketahui diantaranya adalah Size Effect dan The Day of Week Effect. Size Effect menunjukkan perusahaan kecil menghasilkan risk adjusted retun tertinggi daripad perusahaan jenis besar. Anomali tersebut diperkenalkan Banz dan 
Oki Tjandra Suryo Kurniawan, dan IB. Anom Purbawangsa. Pengujian Anomali Pasar...

Reinganum tahun 1981. Sedangkan The Day of Week Effect menjelaskan pasar modal akan naik hari Jum'at dan menurun hari Senin. Berdasarkan penelitian sebelumnya maka hipotesis yang dapat ditarik adalah Berdasarkan uraian penelitian sebelumnya, hipotesis yang dapat dibuat adalah $\mathrm{H} 1$ : Terdapat return saham Size effect dengan return saham The Day of Week Effect diBursa Efek Indonesia.

\section{METODE PENELITIAN}

Study ini akan mengembangkan suatu bentuk model yang bertujuan untuk menjelaskan pengaruh anomali khususnya size effect dan The Day of Week terhadap dalam melakukan investasi sehingga pihak investor memiliki informasi jenis jenis saham dan periode yang tepat saat pengambilan keputusan. Model penelitian yang terbentuk dapat digunakan untuk memprediksi pengaruh gejala anomali yang terjadi pada return saham dalam Bursa Efek Jakarta dengan tahap awal pengelompokkan perusahaan berdasarkan jenis kapitalisasi dan penutupan harga saham perusahaan setiap minggu. Jenis data dalam penelitian dibagi menjadi dua yaitu : 1). Data kuantitatif yaitu harga penutupan dan harga saham berkapitalisasi besar dan berkapitalisasi kecil pada saham manufaktur pada sektor industri konsumsi diBursa Efek Indonesia periode Januari 2017 - Juli 2017 yang didapat dari sumber www.finance.yahoo.co.id dan www.idx.co.id.2). Data kualitatif yaitu hasil penelitian sebelumnya yang sudah dipublikasikan sebagai acuan. Mendapatkan data tepat diperlukan alat yaitu instrument penelitian. Instrument penelitian suatu alat sesuai untuk menganalisa fenomena alam maupun sosial secara akurat yang disebut variabel penelitian (Sugiyono, 2013). 
Variabel dipergunakan dalam penelitian adalah return saham, sedangkan populasi dan sampel penelitian adalah perusahaan bergerak pada saham sektoral perusahaan manufaktur periode Januari 2017 - Juli 2017 diBursa Efek Indonesia (BEI). Purposive sampling method sebagai metode analisa pemilihan sampel untuk mendapatkan sampel sesuai yang diterapkan, ciri yang diterapkan dalam pengambilan sampel ini adalah perusahaan tersebut melakukan pembagian deviden, stock split dan penerbitan saham baru. Jenis data menggunakan data sekunder yaitu dengan mengunduh data 21 perusahaan manufaktur melalui website keuangan periode Januari 2017-Juli 2017. Metode analisa data menggunakan uji regresi linear dikarenakan variabel yang dihitung lebih dari satu untuk variabel bebas dengan menggunakan pemograman SPSS, perumusan model regresi linear berganda adalah :

$$
Y=\beta_{0}+\beta_{1} X_{1}+\beta_{2} X_{2}+\beta_{3} X_{3}+\ldots \ldots \ldots+\beta_{n} X_{n}+\epsilon
$$

Dimana :

$\mathrm{Y} \quad=$ Rata rata return saham pada periode $-\mathrm{t}$

$\beta \quad=$ Koefisien garis regresi

$\mathrm{X}=$ Hari Perdagangan

$\in \quad=$ Error

Teknik analisa data yaitu dengan menghitung nilai return saham (Rit) selama periode pengamatan dengan persamaan :

$$
\text { ReturnSaham }=\frac{P_{t}-P_{t-1}}{P_{t-1}}
$$

Dimana :

$P_{t}=$ Harga saham waktu sekarang 
$P_{t-1}=$ Harga saham waktu lampau

Dilakukan uji independent sample test pada dua kelompok perusahaan berdasarkan kapitalisasi yaitu kapitalisasi besar dan kapitalisasi kecil. Uji ini ditujukan untuk melihat apakah terjadinya gejala anomali Size Effect pada perusahaan tersebut. Sedangkan uji ANOVA dilakukan setelah mengelompokkan berdasarkan hari perdagangan, hal ini dilakukan untuk melihat apakah terjadinya gejala anomaly The Day of Week Effect. Tahap terakhir dilakukan uji paired sample test untuk menguji signifikansi perbedaan size effect terhadap The Day of Week Effect.

\section{HASIL PENELITIAN}

Deskripsi Statistik Ukuran Perusahaan, Variable dipergunakan adalah nilai return perusahaan terhadap kapitalisasi pasar besar dan kapitalisasi pasar kecil pada periode Januari 2017-Juli 2017 yang dimana dilakukan pemisahan berdasarkan kelompok kapitalisasi tiap perusahaan dan total asset kemudian dilakukan perbandingan kedua kelompok tersebut, berikut hasil data statistika deskriptif pada size effect pada tabel 1 :

\section{Tabel 1}

Deskripsi Statistika Variabel Ukuran Perusahaan terhadap return saham periode Januari 2017 - Juli 2017

\begin{tabular}{lccc}
\multicolumn{1}{c}{ Size Perusahaan } & N & Mean & Std. Deviasi \\
\hline $\begin{array}{l}\text { Kapitalisasi Besar }(>5 \\
\text { Triliun) }\end{array}$ & 9 & 9.769 & 1.269 \\
$\begin{array}{l}\text { Kapitalisasi Kecil }(<5 \\
\text { Triliun) }\end{array}$ & 12 & 1.397 & 1.736
\end{tabular}

Sumber: Data diolah, 2017 
Dari hasil tersebut, return perusahaan berkapitalisasi kecil terlihat lebih kecil dari return perusahaan berkapitalisasi besar dengan perbedaan sebanyak $0.467(<0.05)$ maka dapat disimpulkan terdapat anomali size effect diBursa Efek Indonesia pada perusahaan manufaktur.

Deskripsi Statistika Hari Perdagangan, menggunakan rata rata return dari masing masing kelompok hari Senin sampai Jum'at, dimana dilakukan perhitungan return harian tiap perusahaan kemudian dikelompokkan berdasarkan masing masing hari untuk mencari nilai return tersebut. Berikut hasil dengan uji regresi pada tabel 2 :

Tabel 2

Deskripsi Statistika Variabel Hari Perdagangan terhadap return saham periode Januari 2017 - Juli 2017

\begin{tabular}{lccc}
\hline & N & Mean & St. Dev \\
\hline Return (Y) & 21 & 0.04686 & 0.2078 \\
Senin (X1) & 21 & 0.00138 & 0.00504 \\
Selasa (X2) & 21 & -0.3112 & 0.00942 \\
Rabu (X3) & 21 & 0.00153 & 0.00367 \\
Kamis (X4) & 21 & 0.00031 & 0.00406 \\
Jum'at (X5) & 21 & -0.00087 & 0.00977 \\
\hline
\end{tabular}

Sumber: Data diolah, 2017

Tabel 2 terdapat nilai return pada hari Senin-Jum'at sebanyak 21 perusahaan. Hasil tersebut hari Rabu bernilai return tertinggi sebesar 0.00153 dan terendah dihari Selasa sehbesar -0.3112. Return pada deviasi tertinggi jatuh pada hari Jum'at sebesar 0.00977 dan return pada deviasi terendah jatuh pada hari 
Oki Tjandra Suryo Kurniawan, dan IB. Anom Purbawangsa. Pengujian Anomali Pasar...

Rabu sebesar 0.00367. Berikut pergerakan return saham periode Januari 2017-Juli 2017 dalam bentuk grafik :

Grafik 3

Pergerakan return saham saham

periode Januari 2017-Juli

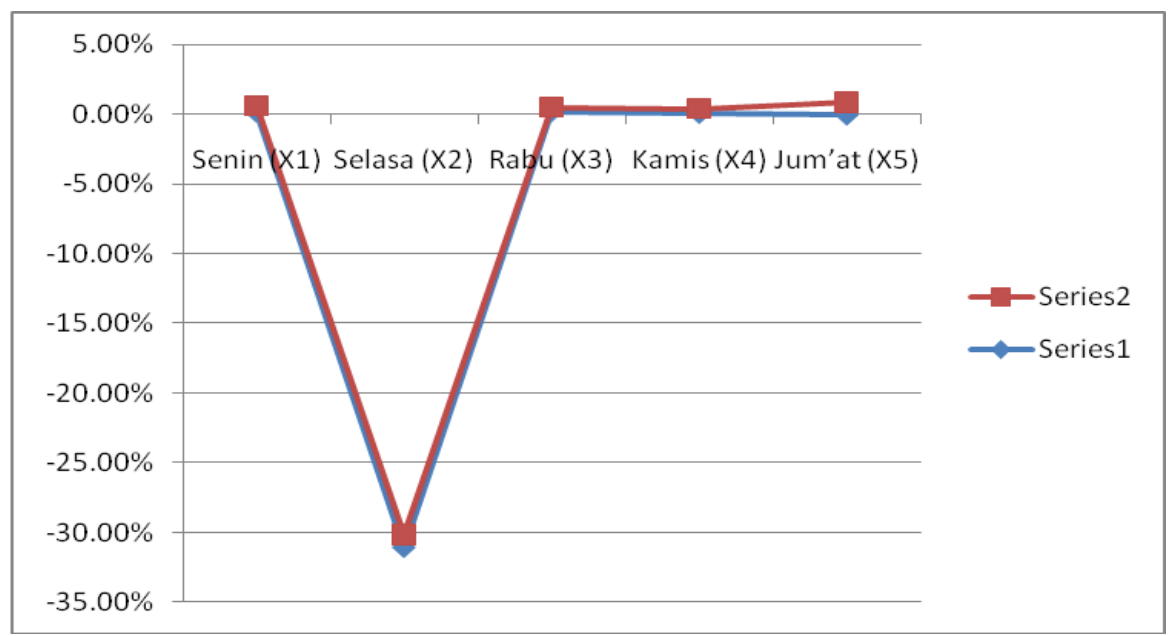

Sumber: Data diolah, 2017

Pada grafik diatas dijelaskan bahwa penyimpangan (anomali) pada hari perdagangan terendah yaitu pada hari Selasa (series 1) dan hari perdagangan tertinggi yaitu pada hari Jum'at (series 1).

Dalam uji hipotesis ukuran perusahaan terhadap return saham, langkah utama adalah menentukan dahulu pembagian perusahaan berdasarkan jenis kapitalisasi nya kemudian dilakukan perhitungan return masing masing perusahaan berdasarkan kelompok kapitalisasi selanjutnya melalui uji beda sampel bebas (independent sample $t$ test) dipakai menjelaskan beda rerata dua jenis sampel saling terkait. Uji hipotesis variable independent pada size effect ditabel 4 


\section{Tabel 4}

Uji hipotesis variable independent Ukuran Perusahaan terhadap return saham periode Januari 2017 - Juli 2017

\begin{tabular}{lccc} 
Kapitalisasi Perusahaan & Sig. (2 - Tailed) & Mean-Difference & $\begin{array}{l}\text { Std. Error- } \\
\text { Difference }\end{array}$ \\
\hline Equal Variances Assumed & 0.016 & 9.62993 & 3.63183 \\
Equal Variances Not Assumed & 0.052 & 9.62993 & 4.23071 \\
\hline
\end{tabular}

Sumber: Data diolah, 2017

Dari hasil tersebut dijelaskan terdapat perbedaan rata rata (mean difference) effect size pada perusahaan besar dan perusahaan kecil sebesar 9.62993 hasil tersebut didapat dari selisih nilai rata rata kapitalisasi perusahaan besar terhadap kapitalisasi perusahaan kecil. Nilai sig. $0.052(<0.05)$ disimpulkan terdapat pengaruh antara rata rata return pada perusahaan kapitalisasi besar terhadap perusahaan kapitalisasi kecil.

Uji ini bertujuan menganalisa pengaruh return hari pada perdagangan beberapa saham pada aktivitas jual-beli pasar modal. Analisa uji ANOVA dan uji hipotesis dilihat pada tabel 5

\section{Tabel 5}

Uji Hipotesis Hari Perdagangan pada return saham perusahaan

\begin{tabular}{lccccc}
\hline \multicolumn{1}{c}{ Model } & Sum of-Squares & Df & Mean-Square & F & Sig. \\
\hline Regression & 0.442 & 5 & 0.088 & 3.142 & 0.039 \\
Residual & 0.422 & 15 & 0.280 & & \\
Total & 0.864 & 20 & & & \\
& & & & & \\
\hline
\end{tabular}

Sumber: Data diolah, 2017

Hasil menunjukkan $\mathrm{H}_{0}<0.05$ atau rata-rata return masing-masing kelompok hari adalah tidak homogen signifikan. Dapat disimpulkan terdapat anomali the day 
Oki Tjandra Suryo Kurniawan, dan IB. Anom Purbawangsa. Pengujian Anomali Pasar...

of the week effect diperusahaan manufaktur diBursa Efek Indonesia dan hanya gejala Tuesday Effect yang disebabkan nilai return yang signifikan negatif (terendah) terjadi pada hari selasa sebesar .-0.3112 dibandingkan dengan hari-hari lainnya. Hasil ini mendukung penelitian Ho (1990), Anggrawal dan Rivoli (1989) dalam Sumiyana (2008).

Uji Hipotesis ukuran perusahaan dan hari perdagangan terhadap return saham bertujuan untuk menganalisa beberapa kejadian yang disebabkan oleh kedua anomali tersebut dan menguji apakah ada tidaknya perbedaan yang ikut mempengaruhi return saham pada perusahaan tersebut. Analisa ini menggunakan uji paired sample test dan hasil uji dilihat pada tabel 6

Tabel 6

Uji Hipotesis Ukuran Perusahaan dan Hari perdagangan terhadap return saham perusahaan

\begin{tabular}{lccc}
\hline & Mean & Std. Dev & Sig. (2 tailed) \\
\hline Return Effect Size & 65.057 & 163.370423 & 0.083 \\
$\begin{array}{l}\text { Return The Day of } \\
\text { Week }\end{array}$ & & & \\
\hline Sumber: Data diolah, 2017 & & &
\end{tabular}

Hasil menunjukkan $\mathrm{H}_{0}<0.05$ atau rata-rata nilai return masing-masing dari dua anomali tersebut, sehingga dapat disimpulkan bahwa terdapat perbedaan signifikan size effect dan the day of the week-effect perusahaan manufaktur diBursa Efek Indonesia.

Uji terhadap dua kelompok ukuran perusahaan berdasarkan kapitalisasi pasar dan asset dengan menggunakan ANOVA tersebut dijelaskan bahwa terdapat perbedaan hasil hipotesis pada size effect dengan return pada perusahaan 
berkapitalisasi kecil terlihat terkecil dari return perusahaan berkapitalisasi besar. Hasil penelitian ini bisa disebabkan karakter pasar modal ataupun metode analisa yang digunakan khususnya pada pemilihan contoh perusahaan berdasarkan ukuran perusahaan. Penelitian sebelumnya yang dilakukan oleh Eugene Fama dan French tahun 1993, 1995, 1996 berfokus pada perhitungan jumlah populasi dengan sampel diuji adalah kelompok perusahaan kecil sebesar $20 \%$ dan kelompok perusahaan kecil sebesar 20\% sehingga dari hasil penelitian ikut berbeda.

Hasil analisis One Way ANOVA pada The day of the week-effect menunjukkan pengembalian periode hari berlainan pada rata-rata pengembalian hari lainnya, pada penelitian ini return terendah pada hari selasa (Tuesday Effect). Dari hasil pada penelitian dijelaskan hari perdagangan mempengaruhi nilai return, sehingga sesuai dengan hipotesis $\mathrm{H} 0$ yang menjelaskan terdapat adanya hari perdagangan satu minggu terhadap return saham. Dari penelitian dapat disimpulkan para pelaku investor akan mendapatkan nilai return lebih tinggi dengan memanfaat pola return tersebut, hal ini dikarenakan adanya return sekuritas harian dalam fenomena tersebut sedangkan pada hasil empiris tidak mendukung teori anomali pasar efisien yang menjelaskan adanya pengaruh hari perdagangan selama seminggu terhadapa return saham. Ada beberapa alasan yang mengakibatkan terjadinya fenomana Tuesday effect. Menurut Ho (1990) dalam Sumiyana (2008) peristiwa ini disebabkan adanya perbedaan zona waktu, yaitu hari selasa di zona Asia Pasifik sesuai dengan hari senin di pasar Amerika sehingga effek hari Senin pada bursa efek Amerika berimbas pada bursa efek di Indonesia, sehingga sebagai pedoman para investor di Indonesia agar melakukan 
Oki Tjandra Suryo Kurniawan, dan IB. Anom Purbawangsa. Pengujian Anomali Pasar...

pembelian saham sebelum closing price hari Selasa dan menjualnya dihari Jum'at sesuai dalam arti investasi yaitu membeli asset saat harga mengalami penurunan dan menjualnya saat harga meningkat.

Dalam uji ukuran perusahaan dan hari perdagangan dalam perolehan return dijelaskan bahwa dengan membandingkan nilai return masing masing anomali didapatkan bahwa tidak terdapat perbedaan signifikan yang terjadi pada perusahaan manufaktur periode Januari 2017-Juli 2017. Hal ini mengindikasikan bahwa rata-rata return yang diperoleh berdasarkan pola perdagangan harian maupun ukuran perusahaan menghasilkan nilai rata-rata return yang sama atau tidak berbeda secara siginfikan. Dari hasil tersebut sebagai pegangan investor dimana investor bisa saja memilih pola perdagangan harian ataupun berpedoman pada ukuran perusahaan sebagai salah satu cara untuk melakukan pemilihan saham untuk mendapatkan return yang lebih tinggi.

\section{SIMPULAN DAN SARAN}

Hasil diperoleh kesimpulan yaitu ukuran perusahaan (size effect) terhadap return saham perusahaan tidak terdapat adanya size effect. Hal ini dikarenakan saham perusahaan kesil memberikan return lebih kecil dari perusahaan besar. Sedangkan pada pengujian hari perdagangan (The Day of Week) terhadap pengembalian saham perusahaan menjelaskan terdapat perbedaan rata rata return dalam satu minggu pada return terkecil terjadi hari Selasa (Tuesday effect) dan return tertinggi terjadi pada hari Rabu. 
Pengujian ukuran perusahaan (size effect) terhadap hari perdagangan (The Day of Week) menjelaskan terdapat perbedaan hasil yang signifikan dikarenakan lemahnya daya beli masyarakat periode tersebut sehingga otomatis mempengaruhi investor saat akan melakukan investasi pada perusahaan tersebut (harian Kontan, 27 Juli 2017).

Saran penelitian bagi investor sebaiknya lebih berhati hati saat berinvestasi di pasar modal yaitu dengan mencari informasi tambahan di perusahaan tersebut. Sedangkan dalam penelitian ini pada saham sektoral tidak terbukti adanya anomali Size Effect dan The Day of Week Effect, sehingga investor tidak selalu bergantung pada anomali tersebut saat pengambilan keputusan berinvestasi.

Saran ada penelitian berikutnya, penelitian ini terbatas hanya dalam pengujian Size Effect dan The Day of Week Effect, sehingga dapat menggunakan pengujian jenis anomali pasar yang lain yang kemungkinan terjadi dalam pasar modal serta menggunakan periode waktu yang berbeda.

\section{REFERENSI}

Abraham dan David L. Ikenberry. 1994. The Individual Investor and the Weekend Effect. Journal of Financial and Quantitative-Analysis Vol. 29, No. 2: 263-277.

Ang, Robert. 2010. Buku Pintar Pasar Modal Indonesia 7 th. Edition. Jakarta : Media Soft Indonesia.

Banz, R, W. (1981). The Relationship Between Return and Market Value of Common Stocks. Journal of Financial Economics 9. PP:3-18. 
Basher, S. A \& P. Sadorsky. 2006. Day of The Week Effect in Emerging Stock Markets. Applied Economics Letters. Vol 13, No 10, pp: 621628.

Basu.S, 1977. Insventment performance of Common Stock in Relation to Their Price Earning Ratios: A Test of Efficient Market Hypothesis. Journal of Finance 32,pp:663-682.

Brooks, R. and Marco Del Negro. 2002. The Rise in Comovement Across national Stock Market:Market Integration or IT Bubble? Federal Roserve Bank of Atlanta Working Paper 17a.

Cahyaningdyah, Dwi, 2004. Analisis Pengaruh Hari Perdagangan terhadap Return Saham: Pengujian Week-Four Effect dan Rogalski Effect di Bursa Efek Jakarta, Tesis UGM. Tidak Dipublikasikan.

DeBondt, W.F.M. dan R.H. Thaler. 1985. Does the Stock Market Overreact?, Journal of Finance, Vol. 40, pp. 793-808.

Elton, E.J., and M.J. Gruber, 1995, Modern Portfolio Theory and Investment Analysis, 5th ed, New York: John Wiley and Sons, Inc.

Fabozzi, Frank. J. 1999. Manajemen Investasi. Jakarta: Salemba Empat.

Fahmi, Irham. 2013. Pengantar Manajemen Keuangan. Bandung : Alfabeta.

Fama, Eugene, 1991, Efficient Capital Markets: II. Journal of Finance Vol.46 No.5.

Fama, E.F and French, K.R. 1992. The Cross Section of Expected Stock Return, Journal of Finance, Vol. 47, No. 2, June, pp. 427-465.

Fitria, Dian Nurlaily. 2009. Pengaruh Day Of The Week Effect Terhadap Return Saham pada Perusahaan yang Terdaftar di Jakarta Islamic Index.

Ghozali, Imam, 2013. Aplikasi Analisis Multivarite dengan SPSS, Cetakan Ketujuh, Badan Penerbit Universitas Diponegoro. Semarang.

Gregorius, Sihombing. 2008. Kaya dan pinter jadi trader dan investor saham. Yogyakarta: Indonesia cerdas.

Gumanti, Tatang Ary. 2011. Manajemen Investasi. Bogor: Mitra Wacana Media.

Gujarati, Damodaran. 2003. Ekonometrika Dasar. Terjemah Sumarno Zein. Jakarta: Erlangga.

Hartono, Jogiyanto. 2013. Metode Penelitian Bisnis (Salah Kaprah dan Pengalaman-Pengalaman.Yogyakarta: BPFE. 
Husnan, Suad. 2001. Teori Portofolio dan Analisa Sekuritas. AMP YKPN. Yogyakarta.

Jones, Charles P. 2014. Investments Analysis and Management. Twelfth Edition.Singapore: John Wiley \& Sons Singapore Pte, Ltd.

Keim, D.B. dan Stambaugh, R.F. 1984. A Further Investigation of the Weekend Effect in Stock Return. Journal of Finance, 39:819-840.

Kusumawardhani, Srihartati. 2001. Analisis Reaksi Berlebihan, Efek Bid Ask, Firm Size dan Likuiditas dalam Fenomena Price Reversal di BEJ. Tesis. Program Pascasarjana Universitas Diponegoro. Semarang.

Lakonishok, Josef dan Edwin Maberly. 1990. The Weekend Effect: Trading Patternsof Individual and Institutional Investors.The Journal of Finance, Vol XLV, Nol.

Maria, Rio Rita, 2009. Pengaruh Hari Perdagangan Tehadap Return Saham. Pengujian Day of the Week Effect, Week Four Effect dan Rogalsky effect di BEl. Universitas Kristen Satya Wacana Salatiga. Jurnal Ekonomi dan Bisnis Vol. XV No 2.

Mufarrocha dkk. 2015. Analisa Pasar Dalam Merespon Penundaan Kenaikan Harga BBM Bersubsidi Dalam BEI. e-Journal S1 Ak Universitas Pendidikan Ganesha Jurusan Akuntansi Program S1 Vol. 3 No.1.

Mulyadi. 2009. Akutansi Biaya. Yogyakarta. STIE YPKPN.

Pandiangan, Octavianus, 2009. Analisis Anomali Pasar Hari Perdagangan Pada Return Saham di Bursa Efek Indonesia, Skripsi USU.

Panji Sedana, Ida Bagus dan Maria Trisandi, Margaretha.2016. Pengujian Anomali Pasar Day of Week Effect Pada Saham LQ45 Di Bursa Efek Indonesia. e-Journal Manajemen Universitas Udayana,vol 5 no 6 .

Pertiwi, et al. 2013. Analisis Nilai Intrinsik dan Harga Jual Saham Blue Chip pada Perusahaan Yang terdaftar di BEI terhadap Overvalued atau Undervalued, Jurnal Equilibrium Vol.3 No.2, pp. 265-271.

Program Study Magister Manajemen Program Pasca Sarjana Universitas Udayana.2010. Buku Pedoman Usulan Penelitian dan Thesis.

Reilly, Frank K dan Brown, Keith C. 2012. Investment Analysis and Portfolio Management, Tenth Edition, South Western Cengage Learning, USA. 
Rudy, Chandra. 2010. Analisis Pemilihan Saham oleh Investor Asing di Bursa Efek Indonesia. Jurnal Ilmu Administrasi dan Organisasi Vol 17, No 2 .

Rystrom, D.S. dan Earl D.Benson. 1989. Investor Psychology and the Dayofthe Week Effect. Financial Analysts Journal, Vol.45.

Sumiyana, 2008. The Day of Week Effect dan Monday Effect : Fenomena yang terbukti tidak konsisten di pasar modal Indonesia. Jurnal manajemen teori dan terapan. Vol 1 No 1.

Swandewi, Mertha. 2013. Abnormal Return Portofolio Winner Loser Saham Manufaktur di PT Bursa Efek Indonesia. Jurnal Akuntansi Universitas Udayana. Volume 5 Nomor1, pp. 85-99.

Tandelilin, Eduardus. 2010. Portofolio dan Investasi Teori dan Aplikasi. Edisi pertama. Yogyakarta : Kanisius.

Trisnawati, Widya dan Wahidahwati. 2013. Pengaruh Arus Kas Operasi, investasi dan Pendanaan Serta Laba Bersih Terhadap Return Saham. Jurnal Ilmu dan Riset Akuntansi. Volume. 1, Nomor 1, pp: 77-92.

Yanuartha, Ramel. 2012. Anomali Size Effect di Bursa Efek Indonesia, Jurnal Kajian Manajemen Bisnis Vol 1 No 1, Fakultas Ekonomi Universitas Negeri Padang.

Zarowin, Paul. 1990. "Size, Seasonality and stock Market Overreaction" Journal of Finance and Quantitative Analysis, Vol 25, Nol, pp.113-125.

www.epaper.kontan.co.id/news/452931/Gejala-Anomali-Ekonomi-Indonesia. 